\title{
Evaluation of Coastal Defence Strategies in Portugal
}

\author{
Rui Taborda \\ GeoFCUL/LATTEX, Lisbon University, C6 - 5º piso, Campo Grande, 1749-016 \\ Lisboa, Portugal, rtaborda@fc.ul.pt
}

Fernando Magalhães

Instituto da Água, Divisão de Ordenamento e Protecção, Av. Almirante Gago Coutinho, 30, 1049 -066 Lisboa, Portugal, fernandom@inag.

\section{Carlos Ângelo}

Urb. Portela, rua 1, 157, 4535 - 330 Paços de Brandão, Portugal

\begin{abstract}
In Portugal, coastal protection has proceeded largely in an ad hoc manner and has been based on the construction of hard engineering protection structures generally constructed to attend emergency situations. This paper presents the results of two case studies that were used to compare the local and global cost-effectiveness of two coastal protection strategies: construction of groin fields and beach nourishment. According to the results of this study, beach nourishment is the most cost effective solution in the Algarve open beaches, with moderate energy conditions. In the high energetic environment of the Aveiro coast, beach nourishment was also shown to be cost effective when a significative fraction of the sediment cell is considered.
\end{abstract}

\section{Introduction}

Presently, most of the Portuguese sandy shorelines are affected by coastal erosion with retreat rates that, in some locations, reach few meters per year. This behavior is related with an important sand deficit that is mainly related to dam construction, sand and gravel exploitation and extensive estuarine dredging for navigation. Shoreline retreat is also enhanced locally by sand retention on coastal structures and by sea level rise although this last factor seems to play a secondary role (circa $10 \%$, according to Ferreira et al., 1990, Andrade, 1990).

The combination of coastal erosion with the huge value of coastline properties and the economic importance of the coastal tourism industry created a management problem that is very difficult to solve. This problem is generally addressed by three methods: hard stabilization, soft stabilization and relocation. Whichever the strategy adopted to cope with the coastal erosion problem, it should be technically sound, environmentally acceptable and economically viable.

In Portugal, coastal protection has until very recently, relied almost exclusively on the use of groin fields. This kind of strategy, which has been used in long-term erosional shorelines without any beach nourishment schemes, stands against the recommended 
practice. In fact, the use of groins as a shore protection method has a very restricted window of application; the fact that groins have been used so ubiquitously reflects a general misunderstanding about their functioning (Headland et al., 1999). This trend started to change in the last years and some alternative solutions have been attempted. However, these solutions have been used without an assessment of cost and benefits related to a particular solution and the first efforts to evaluate the cost-benefit ratio of different solutions are only now being developed, this work providing a re-iteration of the studies presented by Magalhães et al. (submitted). Due to the lack of suitable data, only direct costs for the "hard" and "soft" protection schemes were considered in this study. In the "hard" stabilization method only the costs related with groin construction was considered.

\section{Approaches to Coastal Erosion}

An adequate protective beach scheme is fundamental to any coastal protection plan. Beach protection can be obtained either by hard engineering structures that can be shore-normal (e.g., groins) or shore-parallel (e.g., seawalls or detached breakwaters) or by soft protection methods like beach nourishment. Shore-normal structures are generally used to prevent the cross-shore movement of sand that occurs during storms and the flooding of hinterland areas, while shore perpendicular structures are generally used to reduce longshore sediment transport (Headland et al., 1999). In this paper only groins will be discussed, since they are, by far, the most used structure for coastal protection in Portugal.

\section{- Groin fields}

Groins interrupt littoral drift. Sands accumulate updrift and there is downdrift erosion induced by that blocking, which is sometimes felt several kilometers from the groin, leading, in most cases, to the construction of groin fields. Although it is difficult to estimate the extent to which a groin field will retard longshore sediment transport, the effectiveness of groins is most strongly related to the length of these structures with respect to the width of the surf zone. Feenstra et al. (1998) have shown that it will be most economical to built relatively short groins focusing on the reduction of the littoral drift in the inner surf zone during moderate wave conditions. These authors also discuss the situations in which groins may be applied and are cost-effective. According to them, these structures are not effective along, namely, steep reflective high-energy sand coasts and macro-tidal sand coasts. Nersesian et al. (1992) have concluded that groin fields can be used to reinforce or to hold protective beach fills and that bypassing of longshore sediment should be ensured.

One fundamental aspect of the functional design of groins is related to the ratio between groin spacing (gs) and groin length (gl). According to US Army Corps of Engineers (2002), a ratio of $2-3$ is required for the proper functioning of shore-normal groins.

\section{- Beach Nourishment}

As stated by Headland et al. (1999) "Beaches offer storm protection through a natural dynamic response to vary waves and water levels. Accordingly it is difficult to provide better shore protection than that offered by a beach". Since artificial nourishment emulates nature itself, it is the most effective and friendly protection alternative. Beach 
nourishment is described in many papers and books, the excellent reviews by Dean (2002) and Douglass (2002) providing outstanding examples. Beach nourishment is a soft protective and remedial measure that leaves a beach in a more natural state than hard structures and preserves its recreational value. It is a popular option in highly developed areas with heavily used beaches and valuable beachfront real estate, especially during the early onset of erosion. This option has been the worldwide selected alternative for shore protection since the 1960s. A good example is Miami Beach, Florida, US, which was renourished in 1979 at a cost of around $52 \times 10^{6} €$. Attendance at the beach increased from 8 million in 1978 to 21 million in 1983. Globally, there was a $700 €$ return for every $1 €$ invested in beach nourishment (Houston, 1996).

In the cases where there is a systematic sediment deficit, where the coast suffers from a chronic erosion problem, the artificial nourishment will be subject to the same erosion and the beach fill design should be concerned with the regular maintenance cost. This issue is related to a main weakness that is related with beach fill operations as the general public, if not properly informed, will considered the beach fill a failure and reclaim a more "visible" protection scheme.

In Portugal, soft protection schemes have been only been used in relatively sheltered beaches and, in general, with fixed structures to prevent end losses. Examples can be found in the Algarve: Praia da Rocha (Gomes and Weinholtz, 1971), Alvor (Teixeira, 1999), Cabanas Island (Dias et al., 2003), Cacela Peninsula (Ângelo, 2001, Dias et al., 2003); and in low-energy pocket and estuarine beaches on the west coast (Andrade et al., in press; Ministério do Ambiente, 1999).

\section{Case Studies}

Two case studies, which suffer from chronic coastal erosion problems, were used for the comparison of the local and global cost-effectiveness of coastal defence strategies: Costa Nova / Vagueira, south of Aveiro, in the west coast and Quarteira / Vale do Lobo, in the south coast (figure 1). Both sites are located on open sandy coastal stretches and are characterized by large differences in energy levels and magnitudes of littoral drift processes.

Data used in this study was obtained from actual construction costs while maintenance costs have to be estimated from the available data and literature. In what concerns beach nourishment expenditure at these coastal stretches, beach nourishment costs were estimated taking into account the saturation of the littoral drift, the unit cost of sand for some nourishment projects in Portugal and the availability of offshore sand sources.

\section{- Quarteira/Vale do Lobo}

The analyzed coastal stretch is represented by a narrow sand beach backed by medium to low height (10 to $15 \mathrm{~m}$ ) cliffs which develops in poor consolidated red sandstones. These cliffs are the main source of sand that feeds the longshore drift, which has a net residue of the order of $10^{4}$ to $10^{5} \mathrm{~m}^{3} / \mathrm{y}$ directed eastwards (Andrade, 1990). This coastal stretch suffered from chronic erosion problems which were reported at least since 1940, with mean retreat rates for the period 1958/1969 in the order of $0.5 \mathrm{~m} / \mathrm{y}$ (Correia et al., 
1994). In order to stop coastal erosion at one of the largest tourist villages in Algarve, several groins were built in the decade of 1970 in front of Quarteira, inducing, along with the Vilamoura marina jetties, the interruption of the eastward littoral transport. As a consequence, there was a net increase in cliff retreat rates, which attained, during the period of 1974/80, a mean rate of up to $7.5 \mathrm{~m} / \mathrm{y}$ downcoast of the groin field, at Forte Novo (Correia et al. 1994; Marques, 1997). Presently, the Quarteira groin field has 6 groins, $100 \mathrm{~m}$ to $140 \mathrm{~m}$ long, which protect a coastal stretch of approximately $1500 \mathrm{~m}$ (figure 2).
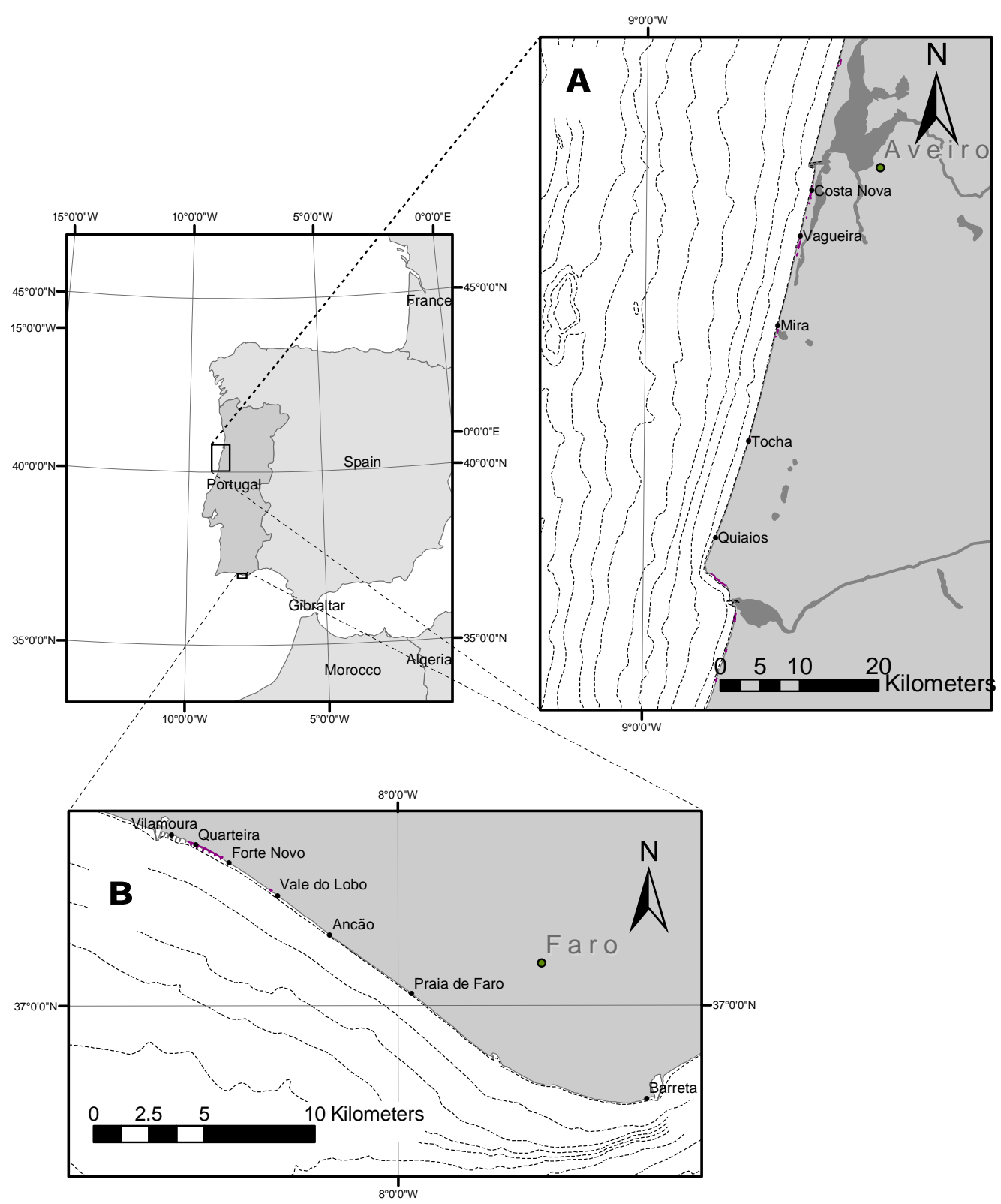

Figure 1. Location map of case studies: A) Costa Nova/Vagueira; B) Quarteira/Vale do Lobo.

Due to the trapping of sand in the groin field the downcoast progressive erosion of the beach started to threat other major tourist resorts, increasing the pressure to build 
protection structures. This could lead to a never ending spiral of protective structures that begun with a rip-rap construction to protect Vale do Lobo swimming pool in $1984 / 85$, and ultimately could lead to the construction of a groin field ending only at Barreta, approximately $25 \mathrm{~km}$ to the east.

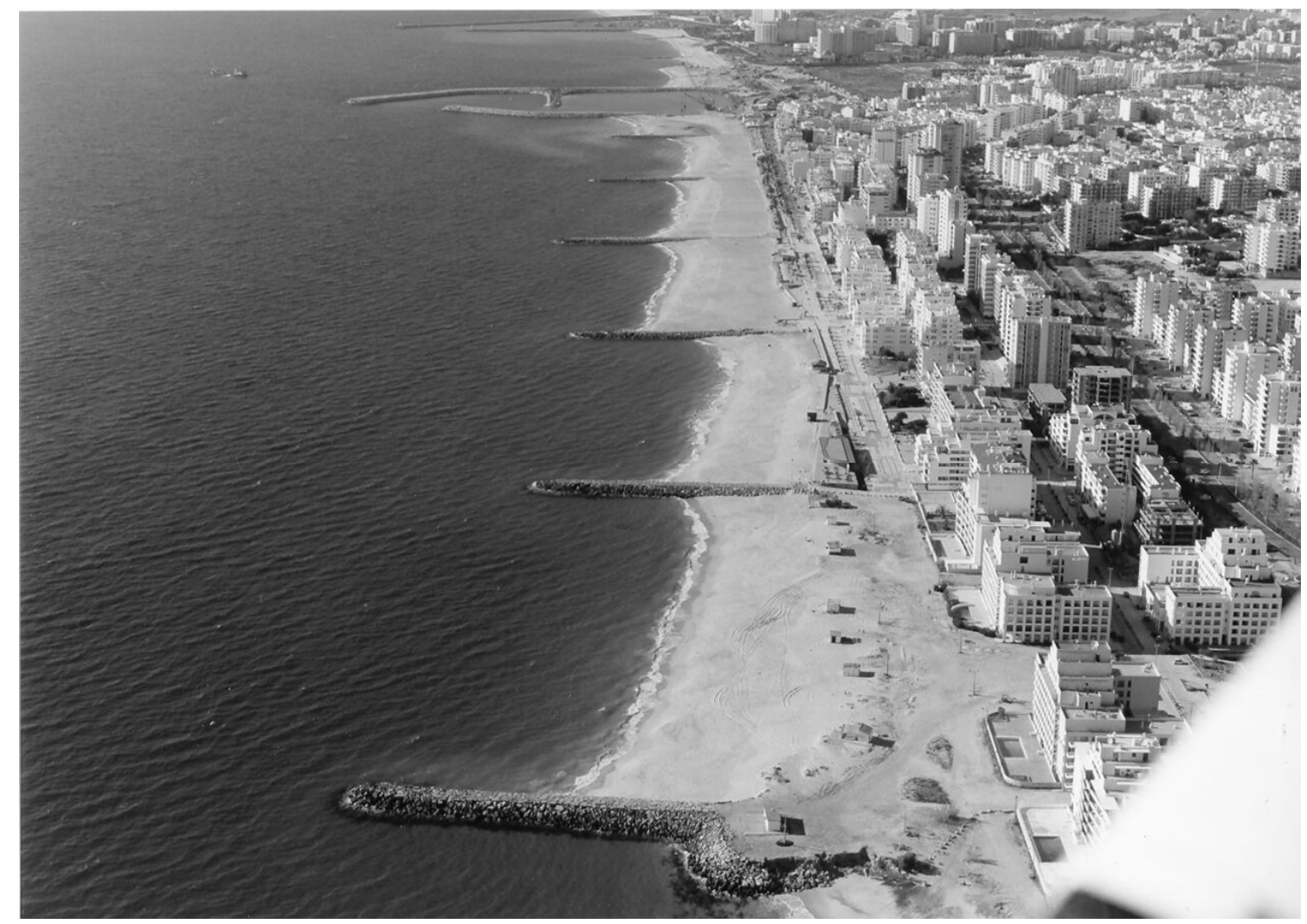

Figure 2. Aerial view of coastal structures in front of Quarteira.

To estimate the actual cost related with the building of protective hard structures in this coastal stretch, data from similar structures recently built in the Algarve coast was used. A mean building cost of 4,000 $€$ per meter of structure groin was found, reasonably agreeing with Van Rijn (1998) estimates of 2,500 to 4,000 U\$. Assuming that the maintenance of these structures increases their cost by a factor of 3 over 50 years (Van Rijn, 1998), an estimated cost of $12,000 €$ / meter structure is obtained. Using a value of 2 for the ratio gs/gl, meaning that each meter of groin should protect 2 meters of shoreline, which is about the same that is used to protect that coastal stretch in front of Quarteira, an estimated cost over 50 years of 6,000€/ m, which is equivalent to an average cost of $120 €$ per meter of shoreline per year.

Due to the tourist importance of the area, the political option for the coastal defence of this sandy stretch has overturned and it was decided to artificially nourish these beaches. This option would enable the maintenance of the environmental values of the region and the width of the beaches and cliffs, one of the most valuable aspects of the region (Veloso-Gomes et al, 2003). The artificial sand nourishment begun in 1998 and was finished on the first week of January 1999, involving the deposition of $600000 \mathrm{~m}^{3}$ of sand, pumped from offshore, from a distance of $4 \mathrm{~km}$ and depths between $16 \mathrm{~m}$ and $20 \mathrm{~m}$, along $1400 \mathrm{~m}$ shoreline (Teixeira et al., 1998). The actual cost of this operation 
was 2.4 M €, which should be supported, in equal shares, by government authorities and Vale do Lobo Resort.

Unfortunately, no monitoring program was conducted after the nourishment so the relevance of this operation for the protection cost estimation is limited; nevertheless, it can give some guidance on that matter. In this case, assuming the need for long term nourishment of a volume equal to the potencial net longshore drift (100 $000 \mathrm{~m}^{3} / \mathrm{yr}$ ) and a cost of sand of $2.5 € / \mathrm{m}^{3}$, the protection cost per year would be around $250000 € / \mathrm{yr}$. The present estimate for sand cost, that was obtained directly from contractors, is somewhat lower than that obtained for the Vale do Lobo nourishment $\left(4.0 € / \mathrm{m}^{3}\right)$ but is roughly in the middle of the interval presented by Muñoz-Perez et al. (2001) for 38 restorations operations carried out in 28 beaches along the Gulf of Cadiz which have similar conditions. There is still a large uncertainty concerning the average longshore drift volume along the coast. While some authors refer a volume of $10^{3} \mathrm{~m}^{3} / \mathrm{yr}$, others estimate a longshore drift two order of magnitude larger $\left(10^{5} \mathrm{~m}^{3} / \mathrm{yr}\right)$, with most authors pointing to a value between $3 \times 10^{4}$ and $5 \times 10^{4} \mathrm{~m}^{3} / \mathrm{yr}$ (Consulmar, 1995 in Teixeira et al., 1998). In order to have a conservative estimate, the larger value of the interval was used. This estimate agrees reasonably well with present field observations which indicate that the beach width is reaching its pre-fill stage (Pinto, personal communication). However, despite being "lost" after some time in what Vale do Lobo beaches are concerned, sand is not lost to the system. Due to longshore drift, which operates throughout the entire littoral cell, the sand which was used to nourish this coastal stretch moves to eastward beaches. This means that the nourishment, as it stops the cause of erosion (the sand deficit), would ultimately protect the entire coastal sediment cell.

Considering the extension of the nourished coastal stretch, a value of $180 €$ per meter of shoreline per year is obtained. However, because of the role of nourishment in protecting the entire coastal sediment cell, the protection costs will be "diluted" when a larger coastal length is considered, meaning that the protection cost per unit length of sandy shore decreases as larger coastal stretches are taken into account. For example, when considering coastal stretches of $5 \mathrm{~km}$ (Quarteira / Vale-do-Lobo) and $20 \mathrm{~km}$ (Quarteira / Barreta), the maintenance cost will be reduced to $50 € / \mathrm{y} / \mathrm{m}$ and $12.5 € / \mathrm{y} / \mathrm{m}$, respectively. These results show that even for relatively small coastal stretches the beach nourishments cost estimates are much lower that those obtained for the construction of a groin field.

The source of sand is one of the critical aspects concerning beach nourishment design. In this case, studies by Teixeira \& Macedo (2001) have shown that the offshore sources of sand between Quarteira and Barra Nova do Ancão have an estimate volume of at least $5 \times 10^{6} \mathrm{~m}^{3}$, which will be sufficient to saturate the littoral drift for several tens of years.

\section{- Costa Nova/Vagueira}

This coastal stretch is located in the Aveiro district, south of Aveiro lagoon. The coast has a NNE-SSW orientation and corresponds to a linear low sandy coast. It is fully exposed to high energetic Atlantic swell, with a net southward longshore drift around 1 $\times 10^{6} \mathrm{~m}^{3} / \mathrm{yr}$ (Oliveira et al., 1982). Presently this area is subject to severe erosion problems, due to the sand retention on the updrift side of Aveiro harbour jetties. When 
the jetties were built, shoreline retreat rates increased dramatically southward of these structures and a retreat of $200 \mathrm{~m}$ up to $300 \mathrm{~m}$ was recorded between 1947 and 1978 (Veloso-Gomes et al., 2003), with mean rates that attained $8 \mathrm{~m} / \mathrm{yr}$. This situation has led to the construction of the Costa Nova groin field, which induced retreat values as high as $50 \mathrm{~m}$ in the two-year period after their construction (Dias, 1990). A total of eleven groins were built in the period 1972/73 to protect this coastal stretch (Oliveira et al., 1982; Oliveira, 1990). However, the present-day situation, as evident from the analysis of aerial photographs, is somewhat different, with 7 groins and almost $2 \mathrm{~km}$ of seawalls (figure 3). The characteristics of the identifiable defence structures are given in Hidrotécnica Portuguesa (1997) and in Veloso-Gomes et al. (2002).

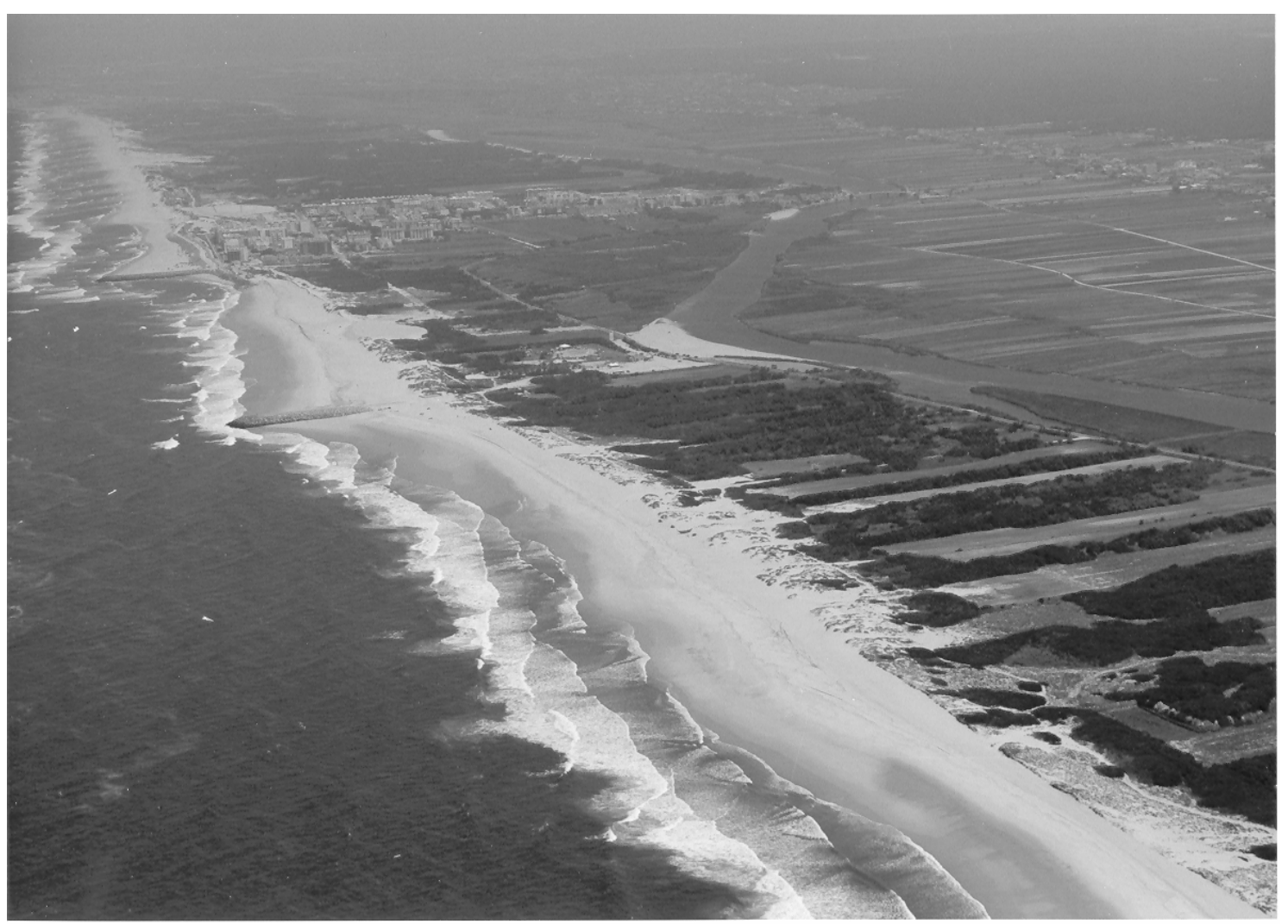

Figure 3. Aerial view of coastal structures in front of Vagueira.

Despite this protection scheme, the recession in this stretch is more serious that the previous. According to Veloso-Gomes et al. (2002), the shoreline will it is predictably retreat to a position that will result in the breaking of a new or more inlets in the Ria de Aveiro. This situation has been prevented by emergency works, which have been executed in the last few years by locals and by the local and central administration authorities in order to prepare more sound solutions. Presently this coastal stretch is protected by a very vulnerable dune system that needs to be artificially repaired or reconstructed otherwise it may result in flooding of the rich agricultural hinterland areas. If a new inlet breaks, the southern lagoon system will suffer the direct influence of coastal waters and the agricultural lands will be saline with strong impacts on the ecosystems. 
According to the Eurosion project (www.eurosion.org) coastal erosion in this area has already caused severe economical losses by reducing the frequentation of beaches, estimated of half a million people during summer in Aveiro. In the same period the cost for creating and maintaining efficient coastal protection works has resulted in lower value for land properties established along the coast (down to $80 \%$ of the initial value in some places).

To estimate the protection cost using a groin field, data from two $220 \mathrm{~m}$ - length groins were recently built south of Cost Nova in the ambit of the Portuguese Water Institute (INAG)'s Coastal Zone Management Plan, was used. Each groin has costed about $2,000,000 €$; that is the cost of each meter of these structures was around 9,000€. This value is clearly above Quarteira / Vale do Lobo and Van Rijn (1998)'s estimates for groin cost $(2,500-5,000 € / \mathrm{m}$ structure) but is justified by the high energetic characteristics of the coast. Assuming, that the maintenance of these structures increases their cost by a factor of 3 over 50 years (Van Rijn, 1998), an estimated cost of 27,000 $€ / \mathrm{m}$ groin is obtained. Using a value of 3 for the ratio gs/gl meaning that each meter of groin should protect 3 meters of shoreline (the maximum value suggested by US Army Corps of Engineers, 2002 and similar to the one presently used for coastal protection in a Portuguese Coastal stretch with similar characteristics Espinho-Paramos), this leads to an estimated cost over 50 years of $9,000 € / \mathrm{m}$ shoreline or $180 € / \mathrm{m} / \mathrm{yr}$, which can considered a relatively high protection cost. On the other hand, the maintenance costs for the period 1975-1997 (Hidrotécnica Portuguesa, 1997) suggest that Van Rijn (1998)'s estimates for such costs are underestimated in the case of Costa Nova, meaning that value could be even higher.

In this high energetic environment, the unit cost of nourishment sand should also be higher than the previous, so the average cost was estimated as $3 € / \mathrm{m}^{3}$. For an overall volume in the order of $10^{6} \mathrm{~m}^{3} / \mathrm{y}$ (the assumed littoral drift, not accounting for the present transposition at Aveiro inlet, which was hypothetically estimated by Oliveira (1997) to be around $2 \times 10^{5} \mathrm{~m}^{3} / \mathrm{yr}$ ) that is required for the system to become saturated, a global cost of $3 \times 106 € / \mathrm{m}^{3} / \mathrm{yr}$ is expected. As discussed in the previous case, when the littoral drift becomes saturated at a given local the same holds true for the entire downdrift coastal stretch. Considering littoral stretches of $5 \mathrm{~km}$ (Aveiro jetties / Vagueira Norte), $20 \mathrm{~km}$ (Aveiro jetties / Mira) and $50 \mathrm{~km}$ (Aveiro jetties / Quiaios), the corresponding protection costs are about $600 € / \mathrm{m} / \mathrm{y}, 150 € / \mathrm{m} / \mathrm{y}$ and $60 € / \mathrm{m} / \mathrm{y}$, respectively. These results show, that even in this high energy coast with a large longshore drift magnitude, beach nourishment can be a cost-effective solution for coastal protection.

In this case, where huge values of sand are needed for beach nourishment maintenance, the offshore sand borrow site is one of the main concerns when considering the viability of this strategy. Several works carried out in the Portuguese mainland coast (e.g. Dias et al., 1980; Magalhães, 2001, 2003) have identified large amounts of sand and gravel deposits in the continental shelf offshore Aveiro coast, whose characteristics and depth of occurrence make them favorable borrow areas for such operations. In this situation offshore sand requirements could also be strongly reduced with the implementation of a sand bypassing system at Aveiro inlet. 


\section{Conclusions}

In Portugal, the choice of the different options for coastal protection has relied on subjective criteria and not on objective cost-benefit analysis, which has resulted in inappropriate measures of coastal erosion mitigation. To address this issue two case studies were used to compare the local and global cost-effectiveness of a "hard" and a "soft" approaches. The chosen sites are characterized by differences in energy levels and magnitudes of littoral drift processes. It should be point out that the figures presented in this work are based on available data; as more data will become available, cost estimates will be refined. Nevertheless, and despite present uncertainties, some general conclusions on cost-effectiveness of different approaches to coastal erosion at the studied sites can be drawn.

In the lower-energy littoral (Quarteira/Vale do Lobo), artificial nourishment becomes a solution that is very cost-effective, regardless of the length of the coastal stretch considered. In fact, when the all the littoral cell is considered the direct protection costs is one order of magnitude lower that of the groin field approach.

In a high energy littoral (Costa Nova/Vagueira), the protection of the coast by a groin field is more economical than artificial nourishment only when a small coastal stretch is considered. When the protection scheme includes at least a significant part of the littoral sediment cell, as environmentally advisable, beach nourishment becomes the most economical option.

These results show that even in a high energetic coast, with high net longshore drift values, beach nourishment is not only the environmentally preferred method but also the most economic one. It should be also stressed that only direct construction and maintenance cost were considered in this study; if other costs, like recreational benefits, storm damage reduction and property appreciation benefits of the different defence methods, were also taken into account, probably beach nourishment would have an even better cost-benefit ratio compared to the hard stabilization scheme.

The main contribution of the present study is to hopefully increase the public and political awareness to a very serious problem which is related to a critical option concerning coastal erosion and our legacy to future generations.

\section{Acknowledgments}

This is a DISEPLA Group contribution and was partially supported by Fundação da Ciência e Tecnologia thought project PDCTM/P/MAR/15265/99 “CROP”. The authors wish to acknowledge Irmãos Cavaco, S.A. for the Vagueira photograph.

\section{References}

1. Andrade, C., 1990. O ambiente de barreira da Ria Formosa, Algarve - Portugal. $\mathrm{PhD}$ thesis. Universidade de Lisboa, 627 pp. (unpublished).

2. Andrade, C., Freitas,M.C., Cachado, C., Cardoso, A., Monteiro, J., Brito, P. \& Rebelo, L. 2002. Coastal Zones. In: Santos, F.D., Forbes, K. \& Moita, R. (eds.) Climate Change in Portugal. Scenarios, Impacts and Adaptation Measure. Gradiva, Lisboa, 173-219.

3. Ângelo, C. 2001. Técnicas de protecção e de conservação da zona costeira. Uma estratégia de gestão operacional. Tese de mestrado, Fac. Ciências Univ. Lisboa, 168 pp. (unpublished). 
4. Andrade, C. (in press). Monitoring the Nourishment of Santo Amaro Estuarine Beach (Portugal). ). Journal of Coastal Research, SI 39.

5. Bettencourt, P. 1997. Notas para uma estratégia de gestão da orla costeira. Colectânea de ideias sobre a Zona Costeira de Portugal. Associação Eurocoast, Portugal, 265-283.

6. Correia, F., J.M.A. Dias \& T. Boski. 1994. The retreat of eastern Quarteira cliffed coast and its possible causes (preliminary results). Gaia 9, 119-122.

7. Dean, R.G. 2002. Beach Nourishment. Theory and Practice. Advanced Series on Ocean Engineering, World Scientific, 18, 399 pp.

8. Dias, J.M.A. 1990. A evolução actual do litoral portugês. Geonovas, 11, 15-29.

9. Dias, J.M.A., J.H. Monteiro \& L.C. Gaspar. 1980. Potencialidades em cascalhos e areias da plataforma continental portuguesa. Com. Serv. Geol. Portugal, 66: 227-240.

10. Dias, J.M.A., Ferreira, Ó., Matias, A., Vila, A. e Sá-Pires, C. (2003). Evaluation of Soft Protection Techniques in Barrier Islands by Monitoring Programs: Case Studies from Ria Formosa (Algarve - Portugal). Journal of Coastal Research, SI 35, 117-131.

11. Douglass, S.L. 2002. Saving America's Beaches. The Causes of and Solutions to Beach Erosion. Advanced Series on Ocean Engineering, 19, 91 pp.

12. Feenstra, J.F., I. Burton, J.B. Smith \& R.S.J. Tool. 1998. Handbook on methods for climate change impact assessment and adaptation strategies. Nairobi and Amsterdam: UNEP and IES.

13. Ferreira, Ó., J.M.A. Dias \& R. Taborda. 1990. Importância relativa das acções antrópicas e naturais no recuo da linha de costa a sul de Vagueira. Actas do $1^{\circ}$ Simpósio sobre a Protecção e Revalorização da faixa costeira do Minho ao Liz, 157-163.

14. Gomes N. \& M.B. Weinholtz. 1971. Evolução da embocadura do estuário do Arade (Portimão) e das praias adjacentes. Emagrecimento da praia da Rocha e sua reconstituição por deposição de areias dragadas no anteporto. 3as jornadas lusobrasileiras de engenharia civil, III-4, 1-26.

15. Headland, J., Smith, W.G., Kotulak, P., Alfageme, S. 1999. Coastal Protection Methods in Handbook of Coastal Engineering, Editor: J.B. Herbich, McGrawHill, 8.1-8.66.

16. Hidrotécnica Portuguesa, 1997. Plano de Ordenamento da Orla costeira OvarMarinha Grande. Estudos de Base. Volume 2 - Dinâmica costeira e obras de defesa.

17. Houston J.R. 1996. International tourism and U.S. beaches. Shore and beach, 67, 23

18. Magalhães, F. 2001. A cobertura sedimentar da plataforma continental portuguesa. Distribuição espacial. Contrastes temporais. Potencialidades económicas. Doc. Técnico Inst. Hidrográfico, 34, 287 p.

19. Magalhães, F. 2003. Aggregate deposits in the portuguese continental shelf. Thalassas, 19, 23-31.

20. Magalhães, F., C. Ângelo \& R. Taborda (submitted to Thalassas) - Towards the adoption of adequate coastal protection strategies in Portugal

21. Marques F. 1997. Sea cliff evolution: the importance of quantitative studies for hazard and risk assessment, and for planning of coastal areas. Colectânea de 
ideias sobre a Zona Costeira de Portugal. Associação Eurocoast, Portugal, p. 67-86.

22. Ministério do Ambiente, 1999. Programa Litoral/99. 75 pp. Lisboa

23. Nersesian, G.K., N.C. Kraus \& F.C. Carson. 1992. Functioning of groins at Westhampton Beach, Long Island, New York. Proceedings 23rd International conference on coastal engineering, ASCE, New York, 3357-3370.

24. Oliveira, I. M. 1990. Erosão costeira no litoral norte. Considerações sobre a sua génese e controlo. Actas do $1^{\circ}$ Simpósio sobre a Proteç̧ão e Revalorização da faixa costeira do Minho ao Liz, 201-221.

25. Oliveira, I. M. 1997. Proteger ou não proteger ou sobre a vulnerabilidade de diferentes opções face à erosão costeira. Colectânea de ideias sobre a Zona Costeira de Portugal. Associação Eurocoast, Portugal, 205-227.

26. Oliveira, I.M., Valle, A.F. \& Miranda, F. 1982. Litoral problems in the portuguese west coast. Coastal Eng. 1982 Proceedings, III, 1951-1969.

27. Teixeira, S.B. 1999. Alimentação artificial de praias do Algarve. Cidades $e$ Munícipios. Temática: Por um novo litoral, 54-58.

28. Teixeira, S.B.; Furtado A. \& Gaspar, M. 1998. Avaliação do Impacte da Alimentação Artificial da Praia de Vale do Lobo nas Comunidades de Bivalves (Algarve-Portugal). Seminário sobre Dragagens, Dragados e Ambientes Costeiros: 47-56, Associação Eurocoast-Portugal, Porto.

29. Teixeira, S. B. \& Macedo, F. 2001. Prospecção de manchas de empréstimo ao largo de Albufeira (Algarve). Relatório DRAOT Algave, 59 pp.

30. U.S. Army Corps of Engineers. 2002. Coastal Engineering Manual. Engineer Manual 1110-2-1100, U.S. Army Corps of Engineers, Washington, D.C. (in 6 volumes).

31. Van Rijn L.C. 1998. Principles of Coastal Morphology. Aqua Publications, Amsterdam.

32. Veloso-Gomes, F., F. Taveira Pinto, J.P. Barbosa, L. Neves \& C. Coelho. 2002. Littoal 2002. Associação Eurocoast, Portugal: 411-422. 